ORIGINAL ARTICLE

\title{
Non-conveyance of patients: Challenges to decision-making in emergency care
}

\author{
Päivi K. Leikkola*1, Riitta K. Mikkola ${ }^{1,2}$, Mari H. Salminen-Tuomaala ${ }^{3}$, Eija E.M. Paavilainen ${ }^{1,2}$ \\ ${ }^{1}$ Hospital District of South Ostrobothnia, Seinäjoki, Finland \\ ${ }^{2}$ University of Tampere, School of Health Sciences, Tampere, Finland \\ ${ }^{3}$ University of Applied Sciences, School of Health Care and Social Work, Seinäjoki, Finland
}

Received: June 2, 2016

DOI: $10.5430 /$ cns.v4n4p31
Accepted: August 26, 2016

Online Published: September 20, 2016

\begin{abstract}
Background: It has been suggested that emergency care providers' decision-making competence should be strengthened regarding whether or not to transport the patient. This qualitative study describes challenges related to non-conveyance situations from emergency care providers' perspective.

Methods: Data were collected by a questionnaire from emergency care providers of a hospital district in Finland in 2014. Responses to open questions were analyzed using inductive content analysis to examine the difficulty of non-conveyance decisions, reasons for non-conveyance and challenges related to the non-conveyance decision after immediate care.

Results: The majority (70\%) of care providers did not experienced difficulty in making non-conveyance decisions, although those working in basic emergence care found decision-making slightly more challenging than workers in advanced emergency care. Care providers' reasons for not transporting patients were most commonly connected with their assessment of care needs and the conclusion that no hospital care was required. Other reasons involved treating the patient on site, psychosocial reasons and not seeing the patient as an emergency care client. Difficulty of reaching mutual understanding with patients was considered the greatest challenge. Other challenges included worrying about the patient's coping at home and problems in inter-professional co-operation, related to hurry and the concern that doctors did not always document requests for care instructions.

Conclusions: The results suggest that care providers' skills in assessing care needs and making decisions based on assessments are a decisive factor in non-conveyance situations. Reaching a mutual understanding with the patient is the greatest challenge.
\end{abstract}

Key Words: Patient, Family member, Counseling, Emergency care, Non-conveyance

\section{INTRODUCTION}

Not very much is yet known about emergency care administered in the patient's home or in another out-of-hospital setting, and relatively little research knowledge exists on emergency care in general and on decisions not to convey patients to hospital. ${ }^{[1,2]}$ It has been proposed that instead of narrowly focusing on patient care procedures, researchers should develop more comprehensive theories of the whole paramedic practice. ${ }^{[1]}$ Research evidence can be used to promote emergency care providers' professional identity and competence, increase patient safety and bring out the role of the paramedic practice as a source of research topics for nursing science. ${ }^{[1,3]}$

The term out-of-hospital emergency care used in this article refers to the care of acutely ill patients in a pre-hospital setting. ${ }^{[4]}$ Emergency care consists of rapidly changing, chal-

*Correspondence: Päivi K. Leikkola; Email: paivi.leikkola@epshp.fi; Address: Hospital District of South Ostrobothnia, Seinäjoki, Finland. 
lenging situations, which create a sense of urgency and induce stress in care providers. ${ }^{[3]}$ Developing out-of-hospital emergency care is of great importance in order to decrease patient mortality and disability. Effective care delivered in the patient's home or other pre-hospital setting also improves the overall quality of patient care and potentially cuts care costs. ${ }^{[4-6]}$

In Finland, emergency medical services have been organized on a regional basis as a part of the health care system, ${ }^{[7]}$ regulated by the Health Care Act and Decree on Emergency Medical Services. The way of organizing services is defined by each regional hospital district, which means that the contents of the services can vary from one district to another. A population within a single hospital district, however, must be served based on a principle of equality. ${ }^{[8]}$ Finnish law also sets out qualification requirements for emergency health care providers, that is to health care professionals and rescue workers. ${ }^{[8]}$ The introduction of the more explicit qualification requirements a few years ago has been found to improve patient safety and the quality of the care. ${ }^{[9]}$ In Finland, ambulances are divided into basic and advanced level vehicles depending on the qualifications of the staff. A basic level ambulance crew consists of registered nurses, practical nurses and emergency medical technicians, all trained to perform at least basic life-saving procedures. An advanced level ambulance team can only have registered nurses and emergency nurses, qualified in more advanced life support techniques and also prepared to manage multiple patient situations. ${ }^{[10,11]}$ Care providers assess the patient's need for emergency care on site and make a decision on whether and how to convey the patient to further care. In other words, non-conveyance or only treating the patient on location is a possible option. ${ }^{[8]}$

It has been reported that up to $30 \%$ of patients are not transported to hospital following attendance by an emergency crew. ${ }^{[12,13]}$ On the other hand, it has been estimated that $11 \%-61 \%$ of the transports are medically not necessary. ${ }^{[14]}$ Typical reasons for non-conveyance seem to include refusal to travel, minor or no injuries, recovery after treatment on scene, falls in elderly people or a visit by the patient's general practitioner. Sometimes family members decide to arrange their own transport. The non-conveyance decision can be a result of patient-carer negotiation; few patients refuse to travel against advice. ${ }^{[12,15]}$

In recent years, treating emergency patients in their homes has come more to the fore as a development target. ${ }^{[6,12]}$ Care providers treat more diverse patient populations than ever, and to be able to manage well, they must possess a wide range of skills. ${ }^{[2]}$ Especially paramedic field managers, who also participate in patient care, require situational awareness.
They must constantly be aware of what is going on and what might happen next, and they have been found to act out multiple roles based on various categories of information. ${ }^{[16]}$ For some time it has been suggested that care providers should have more to say about whether to convey the patient to hospital or not. ${ }^{[6]}$ A study confirmed that appropriately trained paramedics with extended skills can provide care that is at least as safe as the standard care provided by emergency medical services and emergency departments. ${ }^{[17]}$ Other studies claim that paramedics cannot always safely decide, which patients to transfer to hospital. ${ }^{[18,19]}$ Still, to be able to perform as well as possible, care providers need to have the right information ${ }^{[16]}$ and focused guidelines to support their decision making. ${ }^{[20]}$ Support and training are needed to increase care providers' confidence, and with appropriate training, it is possible to treat even aged patients at home safely. ${ }^{[17]}$

\section{Purpose of the study}

This study deals with non-conveyance of patients following attendance by an ambulance crew. The study was conducted from the perspective of emergency care providers, who represented various professional backgrounds. All participants will be referred to as "care providers" henceforth. The study aims at generating new knowledge of decision-making in emergency care situations, to be used in continuing vocational or professional education and in developing care quality. The new knowledge can also alleviate decision-making on whether or not to convey a patient to hospital.

The research questions were: (1) How difficult was it for care providers to make decisions on non-conveyance; (2) What were the care providers' reasons for not transporting patients to hospital; (3) Which factors related to non-conveyance did the care providers find challenging after the immediate emergency care situation?

\section{METHOD}

\subsection{Research design and sample}

The data collected for this research was mainly qualitative and descriptive. Respondents were emergency care providers of a hospital district in Finland in September-October 2014. A new questionnaire based on literature was developed and tested for this purpose. ${ }^{[21]}$ The questionnaire was sent to all emergency care providers of the hospital district, that is to nurses, emergency nurses, practical nurses and emergency medical technicians $(\mathrm{N}=142)$. The response rate was $53 \%$ $(n=71)$. The questionnaire was sent electronically, as a link to an e-mail. Care providers replied electronically to the investigator directly. They remained anonymous. This paper complements and is a continuation of results reported in our 
earlier article, which deals with emergency care providers' clinical skills. ${ }^{[21]}$

\subsection{Instrument}

The questionnaire, developed for this study, was based on earlier research and literature. It was constructed by an expert panel consisting of four researchers. The electronic questionnaire was tested with emergency care providers $(n=17)$ in June-July 2014. As no amendments were required, this data was included in the actual study. ${ }^{[22-24]}$ The questionnaire started with 8 background questions. Respondents were then asked whether they had experienced difficulty in making nonconveyance decisions. A multiple choice question was used with the options $1=$ no, 2 = yes, and 3 = cannot say. Finally, care providers were presented with two open questions, asking them to describe the reasons for not transporting patients to hospital and any challenging factors or issues related to non-conveyance, experienced after the immediate emergency care situation. The results section of this paper includes care providers' background information, their response to the item on difficulty of making non-conveyance decisions, their reasons for non-conveyance and the challenges they had experienced after the immediate emergency care situation had passed.

\subsection{Validity and reliability}

The validity of this research was addressed by means of the primary validity criteria as synthesized by Whittemore et al. $^{[25]}$ for qualitative research. These criteria involve credibility, authenticity, criticality and integrity. Credibility of the qualitative analysis means that the reader can trust that the interpretations are trustworthy and reflect the experience of participants or the context. Authenticity, which is closely linked to credibility, means reaching participants' lived and perceived meanings and experiences and portraying multiple, sometimes conflicting realities. Criticality refers to the investigators' effort to critically appraise their own solutions, interpretations, assumptions and the effect of their knowledge background. Finally, to ensure valid interpretations grounded within data, integrity should be sought through self-reflection and a self-critical approach. ${ }^{[24,25]}$

The credibility and authenticity of this research was ensured by collecting data from emergency care providers involved in practical care work. Respondents had first-hand experience and conceptions of the challenges related to decision-making. Their uniformity of opinion was expressed in numerous references to the challenges in decision-making, reported both quantitatively and qualitatively. The criticality and integrity of the research was secured by repeated examination of interpretations and careful reporting of the research process. The

Published by Sciedu Press whole research team participated in data analysis, which increased the reliability of the results. The connection between data and interpretation was demonstrated by quantitative data on the challenges and by a detailed description of the analysis.

The reliability of the study may be limited by the fact that data were collected in a single hospital district. Despite a motivating cover letter and reminders the response rate was relatively low, $53 \%$, as is often the case in e-mail enquiries. Having to open a separate link to access the questionnaire may have been one reason for the low response rate. It is also possible that this particular target group was tired of various enquiries and repeated data collection. ${ }^{[26-28]}$

\subsection{Ethical considerations}

Attention was paid to responsible conduct of research and research ethics throughout the study. ${ }^{[24,29,30]}$ The study plan passed the ethical review process, and permission to conduct the study was granted by the hospital. Care providers were informed of the purpose of the study, voluntary participation and anonymity before giving their informed consent. They had the possibility to withdraw at any time, and consent or decline did not affect their work in any way. The research results are reported honestly, neutrally and to the investigator's best understanding. ${ }^{[31,32]}$ Individual care providers' expressions cannot by identified. The research team will store the data electronically until all research projects have been ended and reported on.

\subsection{Data analysis}

The background data were analyzed using SPSS for Windows 22. The results section starts with the care providers' background information: age, sex, qualification, current position, type of employment and work experience in the current position, in emergency care and in health services. These background factors are given in frequencies, percentages, means and ranges. The respondents' age data were reclassified for analysis. The connection between care providers' sex and difficulty of the non-conveyance decision was analyzed using cross tabulation.

Inductive content analyses was used to analyze the qualitative data, ${ }^{[33,34]}$ with the objective of constructing a systematic, condensed description of the phenomenon under study. ${ }^{[31]}$ Words, phrases and thoughts expressed through several clauses were thought of as units to be analyzed. Original expressions were selected, listed and reduced, although some of the expressions were so short that they could not be reduced. In the next stage, the reduced expressions were grouped together as sub-categories and named 
using content-characteristic words. The sub-categories were then grouped under higher order categories and descriptive headings. These categories represent the investigator's constructed explanation of the phenomenon under study. ${ }^{[34-36]}$ The number of expressions for various categories is also reported in the results below.

\section{RESUlts}

The non-conveyance situation, experienced by care providers after the immediate emergency care situation, comprised the care provider's decision-making related to non-conveyance, their reasons for not transporting the patient to hospital and the challenges experienced by care providers in the situation.

\subsection{Background Information}

Care providers' background information is given in Table 1. Their mean age was 34 years. The youngest person was 19 and the oldest 58 . There was an equal number of women and men $(\mathrm{n}=71,50 \%)$. More than half of the respondents worked in basic-level emergency care $(n=93,65.5 \%)$ and the rest in advanced-level emergency services $(n=49,34.5 \%)$. Most care providers had a registered nursing qualification $(60.6 \%)$, while the minority $(39.4 \%)$ held vocational qualifications in practical nursing or paramedics. Most respondents (74.6\%) had a permanent work contract and the rest $(25.4 \%)$ a fixed-term contract.
Table 1. Participants' background information

\begin{tabular}{|c|c|c|}
\hline Background information & $\mathbf{N}$ & $\%$ \\
\hline \multicolumn{3}{|l|}{ Sex } \\
\hline - Female & 71 & 50.0 \\
\hline - Male & 71 & 50.0 \\
\hline \multicolumn{3}{|l|}{ Age } \\
\hline - Under 25 & 23 & 16.2 \\
\hline - 25-34 & 55 & 38.7 \\
\hline - $35-44$ & 40 & 28.2 \\
\hline - Over 45 & 24 & 16.9 \\
\hline \multicolumn{3}{|l|}{ Current workplace } \\
\hline - Basic-level emergency care & 93 & 65.5 \\
\hline - Advanced emergency care & 49 & 34.5 \\
\hline \multicolumn{3}{|l|}{ Qualification } \\
\hline - Practical nurse, EMT & 56 & 39.4 \\
\hline - Nurse & 86 & 60.6 \\
\hline \multicolumn{3}{|l|}{ Type of employment } \\
\hline - Permanent & 106 & 74.6 \\
\hline - Fixed term & 36 & 25.4 \\
\hline
\end{tabular}

Note. EMT = emergent medical technician

In addition to the data shown in Table 2, the study revealed that most respondents $(77.3 \%)$ had worked less than 2 years in their current position. Their mean time in their current work was 1.9 years, with the range from 0.3 months to 13 years. They had an average of 8.3 years' experience of working in emergency care services (range 0.5-34 years) and an average of 10 years' experience of working in the health service (range 0-34 years).

Table 2. Care providers' experience of their current work, emergency care and health service by occupational group

\begin{tabular}{|c|c|c|c|c|}
\hline \multirow{2}{*}{ Background information } & \multicolumn{2}{|c|}{ Practical nurses, EMT } & \multicolumn{2}{|c|}{ Nurses } \\
\hline & $\mathbf{N}$ & $\%$ & $\mathbf{N}$ & $\%$ \\
\hline \multicolumn{5}{|l|}{ Experience of current work } \\
\hline • under 1.5 years & 16 & 29.1 & 17 & 19.8 \\
\hline - $1.5-2.4$ years & 31 & 56.4 & 45 & 52.3 \\
\hline - 2.5 years or more & 8 & 14.5 & 24 & 27.9 \\
\hline \multicolumn{5}{|c|}{ Experience of emergency care } \\
\hline - under 3 years & 19 & 33.9 & 33 & 38.4 \\
\hline - 3-8 years & 16 & 28.6 & 29 & 33.7 \\
\hline - over 8 years & 21 & 37.5 & 24 & 27.9 \\
\hline \multicolumn{5}{|l|}{ Experience of health service } \\
\hline - under 3 years & 14 & 26.0 & 11 & 12.8 \\
\hline - 3-8 years & 16 & 29.6 & 39 & 45.3 \\
\hline - over 8 years & 24 & 44.4 & 36 & 41.9 \\
\hline
\end{tabular}

Note. EMT = emergent medical technician

Table 3 reveals that $19 \%(n=27)$ of care providers found it difficult to make a decision not to transport the patient to hospital, whereas approximately two thirds of them $(n=95)$ did not consider the non-conveyance decision difficult and $14 \%(n=20)$ chose the option cannot say.
The investigators did not discover any statistically significant differences between various groups as regards the background variables. Table 4 shows the results for men and women. A slightly larger proportion of women (24\%) compared to men (14\%) found it difficult to make decisions about non-conveyance. Similarly, there were minor differences in 
the results between those working in basic emergency care (21.5\%) and those employed in advanced emergency care (15.2\%). Finally, an analysis conducted for occupational groups revealed that $25 \%$ of emergency medical technicians, $23 \%$ of practical nurses and $16 \%$ of nurses considered the non-conveyance decision difficult.

Table 3. Care providers' difficulty of making non-conveyance decisions

\begin{tabular}{llll}
\hline & Frequency & Percent & Valid Percentage \\
\hline No & 95 & 66.9 & 66.9 \\
Yes & 27 & 19.0 & 19.0 \\
Cannot say & 20 & 14.1 & 14.1 \\
\hline Total & 142 & 100.0 & 100.0 \\
\hline
\end{tabular}

\subsection{Reasons for non-conveyance}

The request to list reasons for not transporting the patient to hospital yielded a total of 257 expressions, classified and presented in Table 5.

According to care providers, their decision not to transport the patient to hospital was based on their assessment of care needs and, most commonly, on the conclusion that the patient did not require emergency treatment or transport to hospital (121 expressions). The patient required neither transport by ambulance nor emergency procedures or constant observation. It was often decided that the patient could wait until the following day and contact the local health center. Care providers reported that they often advised patients to use their own vehicles or have family members accompany them (e.g. to a health center). In some cases, postponing the treatment by a few hours seemed a better solution than a longer, nighttime transport by ambulance. Several care providers also maintained that sometimes their decision not to transport the patient was due to citizens' too low a threshold to call for help. Patients seemed to expect that an ambulance would always convey them to hospital.

Table 4. Care providers' difficulty of making a non-conveyance decision by sex

\begin{tabular}{|c|c|c|c|c|c|}
\hline & & & \multicolumn{2}{|c|}{ Sex } & \multirow{2}{*}{ Total } \\
\hline & & & Female & Male & \\
\hline \multirow{6}{*}{ Difficulty of non-conveyance decision } & \multirow{2}{*}{ No } & Count & 43 & 52 & 95 \\
\hline & & $\%$ within sex & $60.6 \%$ & $73.2 \%$ & $66.9 \%$ \\
\hline & \multirow{2}{*}{ Yes } & Count & 17 & 10 & 27 \\
\hline & & $\%$ within sex & $23.9 \%$ & $14.1 \%$ & $19.0 \%$ \\
\hline & \multirow{2}{*}{ Cannot say } & Count & 11 & 9 & 20 \\
\hline & & $\%$ within sex & $15.5 \%$ & $12.7 \%$ & $14.1 \%$ \\
\hline \multirow{2}{*}{ Total } & & Count & 71 & 71 & 142 \\
\hline & & \% within sex & $100.0 \%$ & $100.0 \%$ & $100.0 \%$ \\
\hline
\end{tabular}

Table 5. Reasons for non-conveyance

\begin{tabular}{|c|c|}
\hline Generic category & Sub-category \\
\hline Assessment of care needs & $\begin{array}{l}\text { - } \text { No need for conveyance or emergency care } \\
\text { - Later visit to a health center } \\
\text { - Patient is not left alone at home }\end{array}$ \\
\hline Patient treated on site & $\begin{array}{l}\text { - Adequate treatment on site } \\
\text { - Minor injury, disease or symptom } \\
\text { - Chronic or prolonged complaint/old complaint }\end{array}$ \\
\hline Psychosocial reasons & $\begin{array}{l}\text { - Loneliness } \\
\text { - Insecurity } \\
\text { - Social reasons } \\
\text { - Lack of common sense or basic life skills }\end{array}$ \\
\hline The patient is not an emergency care client & $\begin{array}{l}\text { - Drugs or alcohol } \\
\text { - Unnecessary telephone calls } \\
\text { - Refusal to be transported } \\
\text { - Patient is a client of the police } \\
\text { - Patient cannot be found } \\
\text { - Ambulance is not used to transport the patient }\end{array}$ \\
\hline
\end{tabular}


Adequate treatment on site was another common reason for non-conveyance (28 expressions). In these cases, care providers felt that they had been able to administer adequate care on site, so that it was safe for the patient to stay at home. The situations mentioned involved pain alleviation (for example for back pain), nose bleeds, gluing wounds, lifting and examining patients who had fallen and treating low blood sugars and shortness of breath. Secondly, patients often had minor physical injuries or symptoms (18 expressions). Examples given by respondents included mild hypertension or fever, minor wounds, gastritis, transient attacks, flu, diarrhea, falls (without injury) and laryngitis. Thirdly, chronic or prolonged conditions were also mentioned as a reason for non-conveyance (26 expressions). In these cases, the patient's complaint was not acute or had not deteriorated significantly, so no emergency treatment was required. The symptoms had persisted for weeks or months. The examples given by care providers involved prolonged stomach complaints, constipation, poor general condition, prolonged flu and chronic back pain.

Respondents also reported that psychosocial reasons sometimes resulted in non-conveyance. The patient's loneliness was mentioned in 9 expressions. Sometimes patients had called for an ambulance, because they had felt frustrated, hoping for help for a prolonged complaint, or because they had felt insecure about their coping at home. In some cases, patients had called for help for social reasons. For example, a lonely elderly person or an intoxicated client had wished for someone to talk to. Finally, it was suggested that lack of common sense or basic life skills sometimes resulted in unnecessary calls.

Last, respondents often felt that the patient was not an emergency care client and did not require transport to hospital. Users of drugs and alcohol were mentioned specifically (22 expressions). Strongly intoxicated persons sometimes called an ambulance, because they wanted immediate rehabilitation or had run out of drink. Persons, who refused to be transported by ambulance, were clients of the police or could not be found, were not considered emergency care clients either. Sometimes clients were not conveyed to hospital by ambulance but by another means of transport.

\subsection{Challenges related to non-conveyance}

As a response to the last question care providers reported, which issues or factors related to non-conveyance they had found challenging after the emergency care situation. A total of 192 expressions were obtained.

Table 6. Challenges related to non-conveyance

\begin{tabular}{ll}
\hline Generic category & Sub-category \\
\hline \multirow{2}{*}{ Difficulty of reaching mutual understanding } & - No mutual understanding of non-conveyance with the patient and family member \\
& - Problems in transport \\
& - Patient requires special attention \\
Patient’s coping at home & Insecurity about patient’s coping at home \\
& - Care provider's responsibility for non-conveyance decision \\
Co-operation between professionals & Home care assistance \\
\hline
\end{tabular}

Table 6 summarizes the challenges related to the nonconveyance decision. According to care providers, the difficulty of reaching mutual understanding was the most challenging factor (72 expressions). The patient and/or family member did not always agree with the non-conveyance decision; the patient and/or family member had a different opinion compared to the care providers' opinion. Sometimes patients or family members did not understand why the patient was not conveyed to care. Some of them thought that patients transported by ambulance were treated faster and could avoid queuing at the emergency clinic. Some patients, especially older persons, and family members had the misconception that an ambulance always transported the patient to hospital. Some of them thought that the destination would always be a central hospital, rather than a minor hospital or health centre. Care providers reported having felt pressurized to transport the patient; sometimes conveyance was demanded, although the patient's condition clearly did not require hospital care. Respondents also mentioned that reaching a mutual understanding was difficult with patients, who required special attention. Confused patients, users of intoxicants and aggressive patients were listed as examples.

Worrying about the patient's coping at home was another challenge mentioned by care providers (21 expressions). The patient did not necessary require hospital care, but respon- 
dents were insecure about the patient's coping at home otherwise. Especially leaving alone-living or old persons at home was sometimes considered problematic. Care providers also commented on their responsibility for non-conveyance decisions. Some of them expressed their insecurity regarding the decisions (9 expressions) and the range of responsibility from assessment and examination of the patient to diagnostics and non-conveyance decisions. Situations, in which there was a possibility of the patient making another telephone call for help, caused insecurity in care providers, as did the concern that the patient might not understand the home care and follow-up instructions (24 expressions) or might not receive adequate assistance from the home help service. Patients with ambiguous symptoms (6 expressions) were another source of insecurity; it was not always possible to find a clear explanation for the illness or the patient was a so-called borderline case. Worry and fear about making an incorrect decision when leaving the patient at home was mentioned (13 expressions); the patient might deteriorate despite careful examination and treatment. A few respondents commented that in case of insecurity, it was better to convey the patient to hospital.

One more area in which challenges were reported in this study involved the co-operation between professionals. Care providers co-operated with doctors of the emergency clinic, consulting them by telephone. Sometimes care providers felt that the doctor did not concentrate sufficiently on the current situation (9 expressions). Secondly, care providers were not always certain if the doctor had entered onto the patient's records the information that the ambulance crew had requested care instructions.

\section{Discussion}

Emergency care providers require a wide range of competencies to be able to encounter acutely ill patients and provide high quality emergency care. ${ }^{[13,17]}$ In this study, most care providers $(70 \%)$ did not consider it difficult to decide about the patient's non-conveyance to hospital. The decisions were slightly more difficult for care providers working in basic level emergency services than for those in advanced level emergency care. Women also found it more difficult to decide about the patient's transport than men. It has been proposed that care providers should have more possibility to decide about non-conveyance. ${ }^{[6]}$ This study indicates that such a development might well be possible.

Patients are not conveyed to hospital care for a variety of reasons. This study revealed that non-conveyance was based on a care needs assessment or on adequate treatment provided on site. Sometimes the reasons were psychosocial or it was decided that the patient was not a client of emergency care services. The most common reason, according to respondents of this study, was care providers' assessment of the patient's situation. ${ }^{[16]}$ As regards psychosocial reasons as a background for non-conveyance, the findings are consistent with earlier research, which states that the emergency team is sometimes only called "to be on the safe side". In many cases the patient does not require transport to hospital ${ }^{[12,20]}$ or cannot be considered a client of emergency care services. As in earlier research, ${ }^{[12,15]}$ it was found in this study that patients sometimes refused transportation or could not be found. The study confirms that emergency care providers assess their patients' emergency care needs and decide about suitable transport on site. ${ }^{[8]}$ Still, non-transport guidelines and practical action models to support decision-making and safe care are also required, as has been recommended before. ${ }^{[20]}$

Today, care providers encounter a greater variety of patient groups than before. ${ }^{[6,12]}$ In this study, reaching a mutual understanding between the care provider, patient and/or family member regarding non-conveyance was found to be the most demanding challenge. The finding is in harmony with earlier propositions that decisions on transport can be commonly negotiated, but are also prone to challenges. ${ }^{[15]}$ Care providers' concern that the patient might not cope at home was another challenge highlighted in this study. The finding brings into mind the importance of gaining correct and adequate patient information to support decision-making. ${ }^{[16]}$ Earlier, a doctor's assessment and decision has been described as the reason for non-transportation. ${ }^{[12]}$ It has also been repeatedly confirmed that emergency care providers' work is characterized by hurry and stress. ${ }^{[3]}$ This study adds to the finding by presenting one more challenge: problems in multiprofessional co-operation, linked to limited time and the care providers' insecurity, whether doctors have always paid adequate attention to patients and if they have correctly documented the ambulance crew's requests for care instructions.

\section{Conclusions}

Emergency care providers have a variety of reasons for not transporting patients to hospital care and they face multiple challenges in the situation related to non-transportation, although most respondents in this study did not find nonconveyance decisions difficult. This research suggests that care providers' skills in assessing care needs and making decisions based on the assessment are essential when having to decide whether the patient should be transported. The care providers in this study possess good self-reported skills in recognizing non-urgent care needs. The study further indicates that reaching a mutual understanding between the patient and care provider can be the greatest challenge linked to the non-conveyance situation. The findings can be used to 
develop emergency care further by improving care providers' CONFLICTS OF INTEREST DISCLOSURE

competence by further training and through emergency prac- The authors declare they have no conflicts of interest. tice.

\section{REFERENCES}

[1] Campeau A. Why paramedics require "theories-of-practice". Australas J Paramed. 2008; 6(2). Available from: http://ro. ecu.edu . au/jephc/vol6/iss2/3

[2] Snooks HA, Kearsley N, Dale J, et al. Gaps between policy, protocols and practice: a qualitative study of the views and practice of emergency ambulance staff concerning the care of patients with non-urgent needs. Qual Saf Health Care. 2005 Aug; 14(4): 251-7. http://dx.doi.org/10.1136/qshc. 2004.012195

[3] Bigham BL, Buick JE, Brooks SC, et al. Patient safety in emergency medical services: a systematic review of the literature. Prehosp Emerg Care. 2012 Jan-Mar; 16(1): 1-20. PMid: 22128905. http://dx.doi.org/10.3109/10903127.2011.621045

[4] Sayed MJE. Measuring Quality in Emergency Medical Services: A Review of Clinical Performance Indicators. Emergency Medicine International. 2011; 2012: 161630.

[5] Brice JH, Garrison HG, Evans AT. Study design and outcomes in out-of-hospital emergency medicine research: a ten-year analysis. Prehosp Emerg Care. 2000 Apr-Jun; 4(2): 144-50. PMid: 10782603. http://dx.doi.org/10.1080/10903120090941416

[6] Cooper S, Barrett B, Black S, et al. The emerging role of the emergency care practitioner. Emerg Med J. 2004 Sep; 21(5): 614-8. http://dx.doi.org/10.1136/emj.2003.011247

[7] Ministry of Social Affairs and Health, Finland. Selvitys ensihoidon ja sairaankuljetuksen kehittämisestä. Sairaankuljetuksen ja ensihoidon kehittämisen ohjausryhmän loppuraportti. [Report on development of ambulance service and prehospital emergency care. Final report of the Steering Group for developing ambulance service and prehospital emergency care]. Helsinki: Reports of the Ministry of Social Affairs and Health; 2009. 35 p.

[8] Ministry of Social Affairs and Health, Finland. Laatu ja potilasturvallisuus ensihoidossa ja päivystyksessä suunnittelusta toteutukseen ja arviointiin. [Quality and patient safety in emergency medical service and on-duty care from planning to implementation and evaluation]. Helsinki: Reports of the Ministry of Social Affairs and Health; 2014 $66 \mathrm{p}$.

[9] National Supervisory Authority for Welfare and Health, Finland. Valtakunnallinen selvitys ensihoidosta. [National report on emergency medical services]. Helsinki: Reports of the National Supervisory Authority for Welfare and Health; 2014. 56 p.

[10] Ministry of Social Affairs and Health, Finland. Ensihoidon palvelutaso. Ohje ensihoitopalvelun palvelutasopäätöksen laatimiseksi sairaanhoitopiireille. [Service level in prehospital emergency care. Instructions for the hospital districts for preparing decisions on service level in prehospital emergency care]. Helsinki: Publications of the Ministry of Social Affairs and Health; 2011. 35 p.

[11] Määttä T. Ensihoitopalvelun organisointi. [Organization of emergency medical services] in: Kuisma M, Holmström P, Nurmi J, Porthan K, Taskinen T (eds.) Ensihoito [Emergency care]. Helsinki: Sanoma Pro Oy; 2013.

[12] Marks PJ, Daniel TD, Afolabi O, et al. Emergency (999) calls to the ambulance service that do not result in the patient being transported to hospital: an epidemiological study. Emerg Med J. 2002 Sep; 19(5):
449-52. PMid: 12205005. http://dx.doi.org/10.1136/emj.1 9.5 .449

[13] Snooks HA, Dale J, Hartley-Sharpe C, et al. On-scene alternatives for emergency ambulance crews attending patients who do not need to travel to the accident and emergency department: a review of the literature. Emerg Med J. 2004 Mar; 21(2): 212-215. http://dx.doi.org/10.1136/emj.2003.005199

[14] Gratton MC, Ellison SR, Hunt J, et al. Prospective determination of medical necessity for ambulance transport by paramedics. Prehosp Emerg Care. 2003 Oct-Dec; 7(4): 466-9. PMid: 14582100. http://dx.doi.org/10.1080/31270300220X

[15] Shaw D, Dyas JV, Middlemass J, et al. Are they really refusing to travel? A qualitative study of prehospital records. BMC Emerg Med. 2006; 6(8): 1-7. http://dx.doi.org/10.1186/1471-227X-6 $-8$

[16] Norri-Sederholm T, Kuusisto R, Kurola J, et al. A Paramedic field supervisor's situational awareness in prehospital emergency care. Prehosp Disaster Med. 2014 Apr; 29(2): 151-9.

[17] Mason S, Knowles E, Freeman J, et al. Safety of paramedics with extended skills. Acad Emerg Med. 2008 Jul; 15(7): 607-12. PMid: 18691211. http://dx.doi.org/10.1111/j.1553-2712.2008 $.00156 . \mathrm{x}$

[18] Hauswald M. Can paramedics safely decide which patients do not need ambulance transport or emergency department care? Prehosp Emerg Care. 2002 Oct-Dec; 6(4): 383-6. PMid: 12385602. http://dx.doi.org/10.1080/10903120290937978

[19] Silvestri S, Rothrock SG, Kennedy D, et al. Can paramedics accurately identify who do not require emergency department care? Prehosp Emerg Care. 2002 Oct-Dec; 6(4): 387-90. PMid: 12385603 http://dx.doi.org/10.1080/10903120290937987

[20] Gray JT, Wardrope J. Introduction of non-transport guidelines into an ambulance service: a retrospective review. Emerg Med J. 2007 Oct; 24(10): 727-9.

[21] Salminen-Tuomaala M, Leikkola P, Mikkola R, et al. Workers' clinical skills at out-of-hospital emergency care. Emerg Med. 2015; (6): 1-6. http://dx.doi.org/10.4172/2165-7548.1000291

[22] Metsämuuronen J. Tutkimuksen tekemisen perusteet ihmistieteissä [Introduction to research for human sciences]. 2nd renewed ed. Jyväskylä, Finland: Gummerus; 2003. 84-87 p.

[23] Heikkilä T. Tilastollinen tutkimus [Statistical research]. 7th renewed ed. Helsinki, Finland: Edita Prima Oy; 2008. 61 p.

[24] Polit DF, Beck CT. Essentials of nursing research: appraising evidence for nursing practice. $7^{t h}$ ed. Philadelphia: Lippincott Williams \& Wilkins; 2010. 146-156, 170-187, 259-262, 273, 412-413 p.

[25] Whittemore R, Chase SK, Mandle CL. Validity in qualitative research. Qual Health Res. 2001 Jul; 11(4): 522-37. PMid: 11521609. http://dx.doi.org/10.1177/104973201129119299

[26] Weiner SP, Dalessio AT. Oversurveying: causes, consequences, and cures. In: Kraut AL (Ed.) Getting action from organizational surveys: new concepts, methods and applications. San Francisco: Jossey-Bass; 2006. 294-311 p. 
[27] Baruch Y, Holtom BC. Survey responses rate levels and trends in organizational research. Hum Relat. 2008 Aug; 61 (8): 1139-60. http://dx.doi.org/10.1177/0018726708094863

[28] Hamilton M. 2009. Online survey response rates and times: background and guidance for industry. J Travel Res. 2009 Feb; 49(1): 121-35.

[29] The National Advisory Board on Social Welfare and Health Care Ethics, Finland. Muistilista eettisten toimikuntien jäsenille ja tutkijoille [Checklist for members of ethical committees and researchers]. Ministry of Social Affairs and Health, Finland. 2009 [cited 2015 May 8]. Available from: http://tukija.fi/c/document_lib rary/get_file?folderld=18753janame=DLFE-680.pdf

[30] Finnish Advisory Board on Research Integrity. Responsible conduct of research and procedures for handling allegations of misconduct in Finland. 2012 [cited 2015 May 18]. Available from: http: //www.tenk.fi/sites/tenk.fi/files/HTK_ohje_2012.pdf

[31] Burns N, Grove SK. The practice of nursing research: conduct, critique \& utilization. 5th ed. St Louis: Elsevier Saunders; 2005.
176-208, 554-555 p.

[32] Kuula A. Tutkimusetiikka. Aineistojen hankinta, käyttö ja säilytys [Research ethics. Data collection, use and storage]. Jyväskylä: Gummerus; 2011. PMid: 21418118.

[33] Graneheim UH, Lundman B. Qualitative content analysis in nursing research: concepts, procedures and measures to achieve trustworthiness. Nurse Educ Today. 2004 Feb; 24(2): 105-12. PMid: 14769454 http://dx.doi.org/10.1016/j.nedt.2003.10.001

[34] Elo S, Kyngäs $H$. The qualitative content analysis process. J Adv Nurs. 2008 Apr; 62(1): 107-15. http://dx.doi.org/10.1111/j .1365-2648.2007.04569.x

[35] Elo S, Kääriäinen M, Kanste O, et al. Qualitative content analysis: a focus on trustworthiness. SAGE Open. 2014 Feb [cited 2015 Jun 29]; 4(1). Available from: http://sgo.sagepub.com/content/ 4/1/2158244014522633

[36] Kyngäs H, Elo S, Pölkki T, et al. Sisällönanalyysi suomalaisessa hoitotieteellisessä tutkimuksessa [The use of content analysis in Finnish nursing science research]. Hoitotiede. 2011; 23(2): 138-48. 